\title{
ANALISIS PENGARUH PELAYANAN DAN FASILITAS TERHADAP KEPUASAN NASABAH PADA PT BANK CENTRAL ASIA TBK CABANG ROXY SQUARE
}

\author{
Hendrik Aprilyanto \\ Program Studi Magister Manajemen Universitas Tarumanagara \\ aprilyanto28@gmail.com \\ Suwinto Johan \\ Program Studi Magister Manajemen Universitas Tarumanagara
}

Masuk : 01-06-2020, revisi : 24-06-2020 diterima untuk diterbitkan : 24-06-2020

\begin{abstract}
This research aims to analyze the impact of service and facilities on customer satisfaction. The variables in this research are service (X1) and facilities (X2) as independent variables while costumer satisfaction $(\mathrm{Y})$ as dependent variable. Data collection was carried out by distributing questionnaires to 100 respondents. This research is a quantitative research and uses analytical methods with the SmartPLS 3.0 program. The result of the coefficient of determination $\left(\mathrm{R}^{2}\right)$ is 0.658 which shows that $65.8 \%$ of customer satisfaction is influenced by independent variables, while the remaining $34.2 \%$ is the effect of other factors that was not examined. From the results of the t test, service and facilities showed a significant influence to the customer satisfaction. The reliability results for all variables in this research provide composite reliability statistics of more than 0.7 , so it can be concluded that the variables used in this research are reliable. The results show that the service and facilities variables have a significantly positive effect towards customer satisfaction. In this case, service is the most influential factor to costumer satisfaction.
\end{abstract}

Keywords: Service, Facilities, Customer Satisfaction

Abstrak: Penelitian ini dilakukan bertujuan untuk mengetahui bagaimana pengaruh pelayanan dan fasilitas terhadap kepuasan nasabah. Variabel dalam penelitian ini adalah pelayanan (X1) dan fasilitas (X2) sebagai variabel bebas sedangkan Kepuasan Nasabah (Y) sebagai variabel terikat. Pengumpulan data dilakukan dengan menyebarkan kuesioner kepada 100 responden. Jenis penelitian ini adalah kuantitatif dan menggunakan metode analitik dengan program SmartPLS 3.0. Hasil nilai koefisien determinasi (R2) sebesar 0.658 yang menunjukkan bahwa 65,8\% kepuasan nasabah dipengaruhi oleh variabel-variabel independen, sedangkan sisanya sebesar 34,2\% adalah efek dari faktor lain yang tidak diteliti. Dari hasil uji t, pelayanan dan fasilitas berpengaruh signifikan terhadap kepuasan nasabah. Hasil reliabilitas untuk semua variabel dalam penelitian ini memberikan statistik composite reliability lebih dari 0,7 , maka dapat disimpulkan bahwa variabel-variabel yang digunakan dalam penelitian ini reliabel. Hasil penelitian menunjukkan bahwa variabel pelayanan dan fasilitas positif signifikan terhadap kepuasan nasabah. Dalam kasus ini pelayanan yang paling berpengaruh terhadap kepuasan nasabah.

Kata Kunci: Pelayanan, Fasilitas, Kepuasan Nasabah

\section{PENDAHULUAN}

Pada era globalisasi sekarang ini, perkembangan industri keuangan atau perbankan di Indonesia mengalami kemajuan yang pesat. Hal ini dapat dilihat dari semakin banyaknya produk dan fasilitas yang ditawarkan oleh pihak-pihak bank. Masing-masing bank berusaha untuk menarik nasabah dengan meningkatkan kualitas dari segi pelayanan, fasilitas, dan dengan teknologi yang terus berkembang, dengan tujuannya adalah untuk memberikan kepuasan penuh dan maksimal bagi para nasabah. 
Dengan banyaknya persaingan bank-bank di Indonesia semakin tinggi antara satu sama lainnya, maka setiap perusahaan akan terpacu untuk memberikan pelayanan dan fasilitas yang sangat terbaik. Dengan adanya kualitas pelayanan yang baik dalam suatu perusahaan akan menciptakan kepuasan para nasabahnya, setelah nasabah merasa puas dengan produk atau jasa yang diterimanya, nasabah akan membandingkan pelayanan yang diberikan oleh perusahaan lainnya. Semakin baik pelayanan dan fasilitas yang diberikan perusahaan akan memiliki lebih banyak nasabah, namun ada beberapa hal yang harus dipahami oleh perusahaan selaku pihak bank, bahwa semakin banyak nasabah maka perusahaan akan semakin sulit untuk mengenali secara teliti.

Menurut Buchari (2001), fasilitas adalah penyedia perlengkapan-perlengkapan fisik untuk memberikan kemudahan pada nasabahnya. Sehingga kebutuhan-kebutuhan dari pengguna fasilitas tersebut dapat terpenuhi. Oleh karena itu para penyedia jasa keuangan atau perbankan juga harus mementingkan fasilitas karena itu akan memberikan kemudahan untuk seluruh nasabah yang menggunakan produk dan jasa masing-masing bank.

Menurut Tjiptono (2007) kualitas pelayanan merupakan sebagai upaya pemenuhan kebutuhan dan keinginan nasabah serta ketepatan penyampaiannya dalam mengimbangi harapan nasabah. Dalam industri jasa khususnya perbankan yang membedakan antara suatu bank dengan bank lain adalah pelayanannya. Ciri khusus pelayanan yang disediakan setiap bank dengan bank lain sudah dapat dipastikan berbeda-beda, karena perbedaan itu yang harus menjadi kunci untuk menjadikan bank menjadi pelayanan yang terbaik agar nasabah akan memilih untuk menjadi nasabah yang setia.

Tujuan penelitian ini untuk mengetahui pengaruh pelayanan terhadap kepuasan nasabah, pengaruh fasilitas terhadap kepuasan nasabah, pengaruh pelayanan dan fasilitas terhadap kepuasan nasabah.

\section{TINJAUAN PUSTAKA}

Ketika perusahaan yang menjual suatu produk semakin sulit mendiferensiasikan produk fisik mereka, mereka beralih ke diferensiasi pelayanan. Bahkan banyak perusahaan yang menemukan banyak keuntungan ketika mereka menghantarkan pelayanan yang baik, baik itu pengiriman tepat waktu, jawaban pertanyaan yang lebih baik dan lebih cepat, atau resolusi keluhan yang lebih cepat. Penyedia layanan mengetahui kelebihan ini dengan baik. (Kotler \& Keller, 2009)

Menurut Groonros (1990) dalam Ratmitno \& Atik (2005) pelayanan adalah suatu aktivitas atau serangkain aktivitas yang bersifat tidak kasat mata (tidak dapat raba) yang terjadi sebagai akibat adanya interaksi antar konsumen dengan karyawan atau hal-hal lain yang disediakan oleh perusahaan pemberi pelayanan yang dimaksudkan untuk memecahkan permasalahan konsumen atau nasabah.

Fasilitas merupakan segala sesuatu yang sengaja disediakan oleh penyedia jasa untuk dipakai serta dinikmati oleh nasabah yang bertujuan untuk memberikan tingkat kepuasan yang maksimal. Fasilitas merupakan segala sesuatu yang bersifat peralatan fisik yang disediakan oleh pihak penjual jasa untuk mendukung kenyamanan nasabah (Kotler, 2009).

Sedangkan menurut Lupiyoadi (2008) Fasilitas merupakan penampilan, kemampuan sarana prasarana dan keadaan lingkungan sekitarnya dalam menunjukkan eksistensinya kepada eksternal yang meliputi fasilitas fisik (gedung), perlengkapan dan peralatan. Yang termasuk fasilitas dapat berupa alat, benda-benda, perlengkapan, uang, ruang tempat kerja. Pihak perusahaan ingin menunjukkan kepada masyarakat dan nasabah didalam penampilan perusahaan mereka, ini juga bisa membuat para nasabah pun akan tertarik untuk masuk dan menjadi bagian dari nasabah perusahaan tersebut.

Menurut Kotler (2002) kepuasan nasabah adalah perasaan senang atau kecewa seseorang sebagai hasil dari perbandingan antar prestasi atau produk yang dirasakan dan yang diharapkan. Mowen \& Minor (2002) mengatakan kepuasan pelanggan didefinisikan sebagai keseluruhan 
sikap yang ditunjukkan oleh nasabah atas barang dan jasa setelah mereka memperoleh dan menggunakannya.

\section{Kerangka Penelitian}

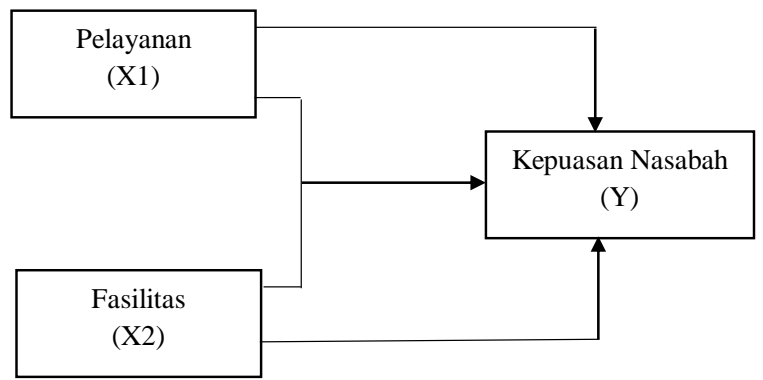

Gambar 1

Kerangka Pemikiran

Sehingga hipotesis dalam penelitian ini adalah sebagai berikut:

Ha1: Pelayanan memiliki pengaruh signifikan terhadap kepuasan nasabah.

$\mathrm{Ha2}$ : Fasilitas memiliki pengaruh signifikan terhadap kepuasan nasabah.

Ha3: Pelayanan dan fasilitas secara bersama-sama memiliki pengaruh signifikan terhadap kepuasan nasabah.

\section{METODOLOGI PENELITIAN}

Jenis Penelitian

Pada penelitian ini bersifat kuantitatif dengan membandingkan dua nilai variabel, yaitu variabel independen (variabel yang mempengaruhi) dan variabel dependen (variabel yang dipengaruhi).

\section{Variabel Penelitian}

Variabel Independen (Pelayanan dan fasilitas) \& Variabel Dependen (Kepuasan Nasabah)

\section{Populasi dan Sampel}

Populasi dalam penelitian ini adalah setiap orang yang pernah datang mengunjungi dan bertransaksi di PT Bank Central Asia Cabang Roxy Square.

Menurut Fraenkel \& Wallen (1993, dalam Aritonang, 2007) ukuran sampel untuk penelitian deskriptif adalah sebanyak 100 subjek tergolong mendasar. Berdasarkan dari pernyataan diatas tersebut, maka jumlah sampel yang diinginkan dalam penelitian ini adalah minimal sebanyak 100 orang nasabah PT Bank Central Asia Tbk Cabang Roxy Square.

\section{Teknik Pengumpulan Data}

Kuesioner merupakan teknik pengumpulan data yang dilakukan dengan cara menyusun pertanyaan secara terperinci yang ada hubungannya dengan tujuan penelitian yang kemudian dibagikan kepada sejumlah responden yang telah ditetapkan.

\section{Teknik Analisis Data}

Uji analisis data pada penelitian ini menggunakan aplikasi SmartPLS dengan teknik SEM (Structural Equation Model). Teknik SEM (Structural Equation Model) merupakan teknik statistik yang digunakan untuk mengolah dan menganalisis hubungan antar variabel - variabel yang ada dalam penelitian ini.

\section{ANALISIS DAN PEMBAHASAN}

\section{Hasil Analisis Data}

Tabel 1

Hasil Boostrapping

\begin{tabular}{|l|l|l|l|}
\hline Variabel & Path Coefficients & T Statistics & P Value \\
\hline Pelayanan $\rightarrow$ Kepuasan Nasabah & 0.475 & 4.241 & 0.000 \\
\hline Fasilitas $\rightarrow$ Kepuasan Nasabah & 0.383 & 3.489 & 0.001 \\
\hline
\end{tabular}

Sumber: Hasil Penelitian 
Berdasarkan hasil boostrapping, maka dapat disimpulkan bahwa terdapat persamaan yaitu $\mathrm{KN}=0.475 \mathrm{P}+0.383 \mathrm{~F}$ dimana nilai path coefficients pada tabel diatas menunjukkan bahwa nilai prediksi dari pelayanan terhadap kepuasan nasabah memiliki arah positif yaitu sebesar 0.475 dan nilai prediksi dari fasilitas terhadap kepuasan nasabah memiliki arah positif yaitu sebesar 0.383 .

\section{Koefisien Determinasi $\mathbf{R}^{2}$}

Tabel 2

Hasil Determinasi $\mathbf{R}^{2}$

\begin{tabular}{|l|l|}
\hline Variabel & $R$ Square \\
\hline Kepuasan Nasabah & 0.658 \\
\hline
\end{tabular}

Sumber: Hasil Penelitian

Berdasarkan tabel 2, dapat dilihat bahwa nilai $\mathrm{R}^{2}$ adalah sebesar 0.658 yang berarti bahwa variabel fasilitas dan pelayanan memiliki prediksi yang tergolong tinggi sebesar 0.658 terhadap kepuasan nasabah yang artinya apabila terjadi perubahan pada variabel fasilitas dan pelayanan, maka kepuasan nasabah juga akan mengalami perubahan sebesar $65,8 \%$ dan sisanya $34,2 \%$ $(100 \%-65,8 \%)$ adalah efek dari faktor lain yang tidak diteliti.

\section{Uji Reliabilitas}

Tabel 3

Hasil Analisis Reliabilitas

\begin{tabular}{|l|l|}
\hline Variabel & Composite Reliability \\
\hline Pelayanan & 0.884 \\
\hline Fasilitas & 0.939 \\
\hline Kepuasan Nasabah & 0.935 \\
\hline
\end{tabular}

Sumber: Hasil Penelitian

Berdasarkan dari hasil analisis yang dapat dilihat pada tabel 3, maka dapat disimpulkan bahwa seluruh composite reliability masing-masing dari variabel memiliki nilai lebih besar dari 0.7, maka dapat disimpulkan bahwa variabel-variabel yang digunakan dalam penelitian ini reliabel.

\section{Uji Hipotesis}

Tabel 4

Rekapitulasi Hasil Pengujian Hipotesis

\begin{tabular}{|l|l|l|}
\hline Hipotesis & Hasil \\
\hline $\begin{array}{l}\text { Pelayanan memiliki pengaruh signifikan terhadap kepuasan nasabah pada PT Bank } \\
\text { Central Asia Tbk cabang Roxy Square }\end{array}$ & Ha1 & Diterima \\
\hline $\begin{array}{l}\text { Fasilitas memiliki pengaruh signifikan terhadap kepuasan nasabah pada PT Bank } \\
\text { Central Asia Tbk cabang Roxy Square }\end{array}$ & Ha2 & Diterima \\
\hline $\begin{array}{l}\text { Pelayanan dan Fasilitas secara bersama-bersama memiliki pengaruh signifikan } \\
\text { terhadap kepuasan nasabah pada PT Bank Central Asia Tbk cabang Roxy Square }\end{array}$ & Ha3 & Diterima \\
\hline
\end{tabular}

Sumber: Hasil Penelitian

\section{PENUTUP}

\section{Kesimpulan}

Berdasarkan hasil analisis data dan pembahasan yang telah dilakukan, maka dapat disimpulkan sebagai berikut:

Pelayanan terbukti memiliki pengaruh positif terhadap kepuasan nasabah, maka dapat disimpulkan bahwa tujuan dari penelitian ini mengenai pelayanan terhadap kepuasan nasabah telah terjawab dan tercapai.

Dari hasil penelitian menunjukkan bahwa fasilitas memiliki pengaruh positif terhadap kepuasan nasabah, maka dapat disimpulkan bahwa tujuan dari penelitian ini mengenai fasilitas terhadap kepuasan nasabah telah terjawab dan tercapai.

Dengan demikian maka dapat disimpulkan bahwa pelayanan dan fasilitas bersama-sama memiliki pengaruh positif terhadap kepuasan nasabah, maka dapat disimpulkan bahwa tujuan 
dari penelitian ini mengenai pelayanan dan fasilitas terhadap kepuasan nasabah telah terjawab dan tercapai.

\section{Saran}

Berdasarkan dari hasil penelitian ini, penulis memiliki saran yang diharapkan dapat bermanfaat untuk para perusahaan dan peneliti berikutnya. Saran-saran tersebut yaitu sebagai berikut:

Bagi akademisi, untuk peneliti selanjutnya disarankan untuk memperluas jangkauan populasi dan sampel, bukan hanya nasabah PT Bank Central Asia Tbk cabang Roxy Square saja melainkan seluruh nasabah yang menggunakan Bank BCA di Jakarta agar dapat melengkapi dan memperkuat penelitian sebelumnya, dan disarankan untuk meningkatkan jumlah responden, menggunakan objek penelitian yang lainnya, menambahkan dan mengembangkan variabel pada penelitian selanjutnya sehingga hasil yang didapatkan bisa lebih akurat dan memperkuat hasil penelitian.

Bagi perusahaan, saran untuk perusahaan adalah memberikan pelayanan dan fasilitas yang sesuai dengan kebutuhan nasabah. Berdasarkan hasil penelitian yang telah dilakukan, bahwa pelayanan berpengaruh paling dominan menentukan kepuasan nasabah maka ini dapat menjadi masukkan untuk perusahaan lebih meningkatkan pelayanan yang maksimal kepada para nasabah. Untuk fasilitas yang masih kurang adalah mesin anjungan tunai mandiri (ATM) dan mesin setor tunai, ini yang akan menjadi saran untuk perusahaan agar dapat menambahkan mesin-mesin agar lebih lengkap dan membuat kebutuhan nasabah tercapai.

\section{DAFTAR PUSTAKA}

Alma, B. (2001). Manajemen Pemasaran dan Pemasaran Jasa. Bandung: Alfabeta.

Aritonang, L. R. (2007). Riset Pemasaran. Bogor: Penerbit Ghalia Indonesia.

Atik., \& Ratmitno. (2005). Definisi Pelayanan. Yogyakarta: Pustaka Belajar.

Gronroos, C. (1990). Service Management and Marketing: Managing the Moment of Truth in Service Competition. Massachusetts: Lexington

Kotler, P. (2002). Manajemen Pemasaran (Edisi Milenium, Jilid 1). Jakarta: Prebalindo.

Kotler, P., \& Keller, K. L. (2009). Manajemen Pemasaran (Jilid 1, Edisi ke-13). Jakarta: Erlangga.

Lupiyoadi, R. (2008). Manajemen Pemasaran Jasa. Jakarta: Penerbit Salemba Empat.

Mowen, C. J., \& Minor, M. (2002). Perilaku Konsumen. Jakarta: Erlangga.

Tjiptono, F. (2000). Strategi Pemasaran (Edisi Kedua). Yogyakarta: Andi. 